\title{
Manejo de Plantas Daninhas na Cultura do Mamoeiro ${ }^{1}$
}

\author{
Weed Control in Papaya
}

\author{
RONCHI, C.P. ${ }^{2}$, SILVA. A.A. ${ }^{3}$, SERRANO, L.A.L. ${ }^{4}$, CATTANEO, L.F. ${ }^{4}$, SANTANA, E.N. ${ }^{4}$ e \\ FERREGUETTI, G.A. ${ }^{5}$
}

\begin{abstract}
RESUMO - Apesar de o controle de plantas daninhas na cultura do mamoeiro representar um dos componentes de grande importância do custo de produção, no mundo e no Brasil, a disponibilidade de informações sobre esse tema é escassa, o que reflete a pouca importância que tem sido dada ao assunto nas últimas décadas. Neste texto são discutidos alguns avanços no manejo integrado de plantas daninhas que têm sido alcançados em vários países, particularmente no tocante à manutenção da vegetação natural ou à introdução de leguminosas na entrelinha de cultivo. Não obstante, várias espécies de plantas daninhas foram identificadas como hospedeiras de vetores de importantes viroses à cultura, com destaque para Commelina benghalensis e Solanum americanum. Isso se reveste de grande importância para o manejo (seletivo) das plantas daninhas, sobretudo na produção integrada de mamão. Também são discutidos, em especial para a região norte do Estado do Espírito Santo, a seletividade de herbicidas, os periodos de controle e as principais características e aspectos práticos sobre o manejo de plantas daninhas na cultura do mamoeiro.
\end{abstract}

Palavras-chave: Carica papaya, herbicidas, manejo integrado, período de competição, seletividade.

ABSTRACT - Despite the fact that weed control entails high costs to crop production, the availability of national and international papers regarding papaya weed control is scarce, showing that little importance has been given to this subject in the last decades. Some integrated weed management advances attamed in several countries are discussed, particularly in the use of both natural groundcover or leguminous plants in the crop interrows. However, several weed species have been identified as host plants of major virus vectors to the crop, such as $\boldsymbol{C}$. benghalensis and S. americanum. Such information is of major importance for selective weed control, particularly in the integrated system of papaya production. The present review also examined herbicide selectivity, weedy periods as well as the main characteristics and practical aspects of weed control in papaya, focusing on the production areas of the northern Espirito Santo State.

Keywords: Carica papaya, herbicides, integrated management, weedy period, selectivity.

1 Recebido para publicação em 7.2.2008 e na forma revisada em 31.7.2008.

2 Professor, Universidade Federal de Viçosa - Campus Rio Paranaíba - Rod. BR 354, km 310, Caixa Postal 22, 38810-000, Rio Paranaíba-MG, <claudiopagotto@ufv.br>; ${ }^{3}$ Professor, Universidade Federal de Viçosa, Dep. de Fitotecnia, Av. PH Rolfs s/n, 36570-000, Viçosa-MG, <aasilva@ufv.br>; ${ }^{4}$ Pesquisador - Instituto Capixaba de Pesquisa, Assistência Técnica e Extensão Rural (INCAPER), Rod. BR 101, Km 151, Caixa Postal 62, 29915-140, Linhares-ES; ${ }^{5}$ Engo-Agro ${ }^{\circ}$ Caliman Agrícola S/A, BR 101, Km 111, Fazenda Santa Terezinha, Caixa Postal 52, 29900-970, Linhares-ES. 


\section{INTRODUÇÃO}

Tradicionalmente, em razão dos tratos culturais necessários à cultura e, principalmente, devido à forma de colheita dos frutos, o mamoeiro é cultivado em amplos espaçamentos (3,6 x 1,8 m-fileira simples; 3,6 x 1,8 x 1,8 m - fileira dupla) (Marin et al., 1995; Costa et al., 2003). Por esses motivos, e também pelo seu porte e arquitetura de copa, mesmo durante a fase reprodutiva (adulta), observa-se grande área de solo exposta na cultura do mamoeiro (ou o sombreamento é mínimo), favorecendo, dessa forma, a germinação, o crescimento e o desenvolvimento de populações de plantas daninhas. Além disso, nas regiões em que o mamoeiro é cultivado, como, por exemplo, em Linhares, região norte do Estado do Espírito Santo, geralmente predominam altas temperaturas $\left(\sim 26{ }^{\circ} \mathrm{C}\right.$ - inverno; $\sim 32{ }^{\circ} \mathrm{C}$ - verão; Siag, 2008), altas irradiâncias (>1.800 $\mu$ molfótons $\mathrm{m}^{-2} \mathbf{s}^{-1}$ ), e praticamente todas as lavouras são irrigadas (Martins, 2003). Esses fatores, somados ao grande aporte de fertilizantes e de matéria orgânica necessários à cultura (Martins, 2003), proporcionam condições muito favoráveis à infestação do solo por plantas daninhas, agravando o efeito destas sobre a cultura. O manejo de plantas daninhas é, portanto, prática comumente adotada na maioria das lavouras de mamão.

As plantas daninhas interferem negativamente na cultura, causando prejuízos econômicos a essa atividade agrícola, sejam eles diretos ou indiretos (Nishimoto, 1993; MederosOlalde, 2000. Atualmente, tem sido utilizada por alguns produtores e recomendada tecnicamente, seja no Brasil (Costa et al., 2003; Carvalho, 2005) ou na Costa Rica (Bogantes \& Mora, 2004), a eliminação das plantas daninhas na linha de plantio e manutenção da vegetação (natural - plantas daninhas ou introduzidas - leguminosas) na entrelinha, tendo em vista as vantagens que esse manejo pode trazer à dinâmica do agroecossistema (Carvalho, 2005). Todavia, existem riscos associados a essa prática, uma vez que algumas espécies de plantas daninhas são hospedeiras de afideos vetores do virus causador de uma das principais doenças da cultura do mamoeiro.

Planta Daninha, Viçosa-MG, v. 26, n. 4, p. 937-947, 2008
Os gastos com o controle de plantas daninhas nos três primeiros meses de cultivo do mamoeiro são elevados, podendo chegar a $R \$$ $1.200,00$ por hectare, como evidenciam os indices técnicos (dados médios de três anos) obtidos de planilhas de custo de produção de empresa do setor, em Linhares. No período desde o transplantio à sexagem, que ocorre aproximadamente aos 90 dias após o transplantio (DAT), realizam-se quatro operações de controle de plantas daninhas, ou seja, uma capina a cada 22-23 dias, distribuídas da seguinte forma: de 15 a 30 DAT - 1a capina (utilizam-se 27 homens dia $\left.{ }^{-1} \mathrm{ha}^{-1}\right)$; de 30 a 45 DAT - $2^{\text {a }}$ capina ( 15 homens dia- ha $^{-1}$ ); de 45 a 60 DAT 3a capina ( 11 homens dia $\left.^{-1} \mathrm{ha}^{-1}\right)$; e de 60 a 90 DAT - $4^{\mathrm{a}}$ capina (6 homens dia ${ }^{-1} \mathrm{ha}^{-1}$ ). Logo, para o controle de plantas daninhas até os 90 DAT, gasta-se, por hectare, o total de 59 homens $\mathrm{dia}^{-1}$, que, a $\mathrm{R} \$ 20,00 \mathrm{dia}^{-1}$, equivale a $R \$ 1.180,00$ ha (Ferregueti, comunicação pessoal). Esses custos de controle elevados mostram a necessidade de desenvolver novas tecnologias para o manejo de plantas daninhas na cultura do mamoeiro recém-transplantada.

Infelizmente, as pesquisas relacionadas ao manejo de plantas daninhas na cultura do mamoeiro, seja no mundo, no Brasil ou mesmo no Espírito Santo, são ainda incipientes. A carência de informações sobre essa área do conhecimento é grande, chegando-se ao ponto de serem feitas extrapolações sobre o manejo de plantas daninhas de outras culturas (ex.: citros) para a do mamoeiro (Carvalho, 2003, 2005). Por exemplo, a quantificação das perdas causadas à cultura em função da interferência das plantas daninhas limita-se a apenas três trabalhos. Verificou-se que plantas de mamoeiro originadas de semeadura direta foram praticamente destruídas pela presença de plantas daninhas (Nishimoto et al., 1973) e que aquelas transplantadas, sob competição, produziram entre 34 e $59 \%$ do rendimento obtido nas plantas livres de interferência (Nishimoto, 1993). Mederos-Olalde et al. (2000), por sua vez, constataram redução de $92 \%$ na produtividade de lavouras sob infestação de plantas daninhas, comparadas àquelas com controle total destas. Nesse caso, parte do efeito negativo provavelmente foi indireta, em razão de as plantas daninhas propiciarem maior incidência de viroses à lavoura. 
Nesta revisão de literatura, procurou-se abordar vários aspectos relativo ao manejo de plantas daninhas na cultura do mamoeiro, considerando-se o incipiente conhecimento cientifico atual sobre esse tema, disponivel e acessivel na literatura mundial e nacional. A grande maioria dos trabalhos ora mencionados foram realizados no Espírito Santo, no município de Linhares; este Estado, na atualidade, é considerado o segundo maior produtor nacional de mamão (752,5 mil toneladas), que detém as maiores produtividades $\left(80,2 \mathrm{t} \mathrm{ha}^{-1}\right)$ (IBGE, 2008). Algumas informações práticas, quando não citada a fonte, são originais e foram obtidas juntamente com o produtor em lavouras comerciais altamente tecnificadas do Espírito Santo.

\section{Periodo crítico de competição ou época de controle}

As culturas e as plantas daninhas, sob certas condições, podem crescer juntas por um período sem prejuízo significativo à produção - denominado de período anterior à interferência. Após esse período, a presença das plantas daninhas pode reduzir a produção da cultura (Buchanan et al., 1982; Pitelli, 1985). Para qualquer cultura, o modo correto de se interferir na competição seria neutralizá-la nas épocas adequadas, ou seja, nos períodos em que as plantas daninhas concorrem efetivamente com a cultura (período crítico de competição) e afetam, conseqüentemente, a produção (Blanco et al., 1982; Radosevich et al., 1996).

Na cultura do mamoeiro, o período crítico de competição (ou período de interferência), a rigor, é absolutamente desconhecido. Carvalho (2003, 2005) menciona que o período crítico de competição, para regiões de Tabuleiros Costeiros (Espírito Santo e Bahia), situa-se entre os meses de setembro e maio. Todavia, esse autor reconhece a ausência de informação sobre o tema e menciona que tal período de competição trata-se apenas de uma extrapolação feita a partir da cultura de citros, porém para ambiente semelhante àquele em que o mamoeiro é cultivado. Tornam-se premente, portanto, pesquisas de campo para se determinar o período de interferência das plantas daninhas com a cultura do mamoeiro. Essa informação permitiria a otimização do manejo de plantas daninhas, seja por reduzir o custo de produção (redução do número de operações de cultivo) ou por prevenir danos ao meio ambiente, decorrentes da eliminação indevida da cobertura vegetal do solo, em épocas inoportunas, que seriam fundamentais na sustentabilidade do sistema agrícola.

Nas lavouras comerciais e convencionais, altamente tecnificadas, em Linhares, o manejo de plantas daninhas na linha de plantio tem sido realizado de acordo com o esquema apresentado na Tabela 1 (Ferregueti, comunicação pessoal). Desde o transplantio até a sexagem, periodo que dura entre três e quatro meses, cerca de três operações são realizadas para controlar as plantas daninhas, com predominância de capinas manuais (uma vez que as plantas de mamoeiro ainda jovens são, de forma geral, sensiveis a herbicidas - Nishimoto, 1997). Após a sexagem, faz-se a amontoa (geralmente mecanizada), independentemente se a lavoura foi plantada em fileira simples (irrigação por gotejamento) ou dupla (irrigação por microaspersão), ou em terreno plano ou sobre pequenos camalhões. A amontoa, por si só, em analogia à arruação feita em lavouras de café (Ronchi et al., 2001), constitui-se numa operação de controle de plantas daninhas. Seguindo-se à amontoa, ou se faz mais uma capina ou, definitivamente, até o final do ciclo, geralmente utiliza-se de herbicidas não-seletivos, em pós-emergência das plantas daninhas. Na entrelinha, o controle é feito com grade, roçadeira ou com herbicidas não-seletivos em pós-emergência das plantas daninhas. É importante ressaltar que, na lavoura irrigada por microaspersão (portanto, cultivadas em fileira dupla), diferentemente das cultivadas em fileiras simples, as plantas daninhas são completamente eliminadas para evitar que a uniformidade de distribuição de água na área, dentro da fileira dupla, pelos aspersores, seja prejudicada (Ferregueti, comunicação pessoal).

Diante do exposto, verificam-se algumas peculiaridades no controle de plantas daninhas na cultura do mamoeiro, que devem ser consideradas ao se estudar o período crítico de competição e as estratégias de controle, sob pena, caso contrário, de os resultados obtidos revestirem-se de pequena ou nenhuma aplicação prática: o controle de plantas daninhas é subdividido em duas fases - antes e depois da 
Tabela 1 - Esquema do manejo de plantas daninhas na linha de plantio do mamoeiro, ao longo de seu ciclo de vida

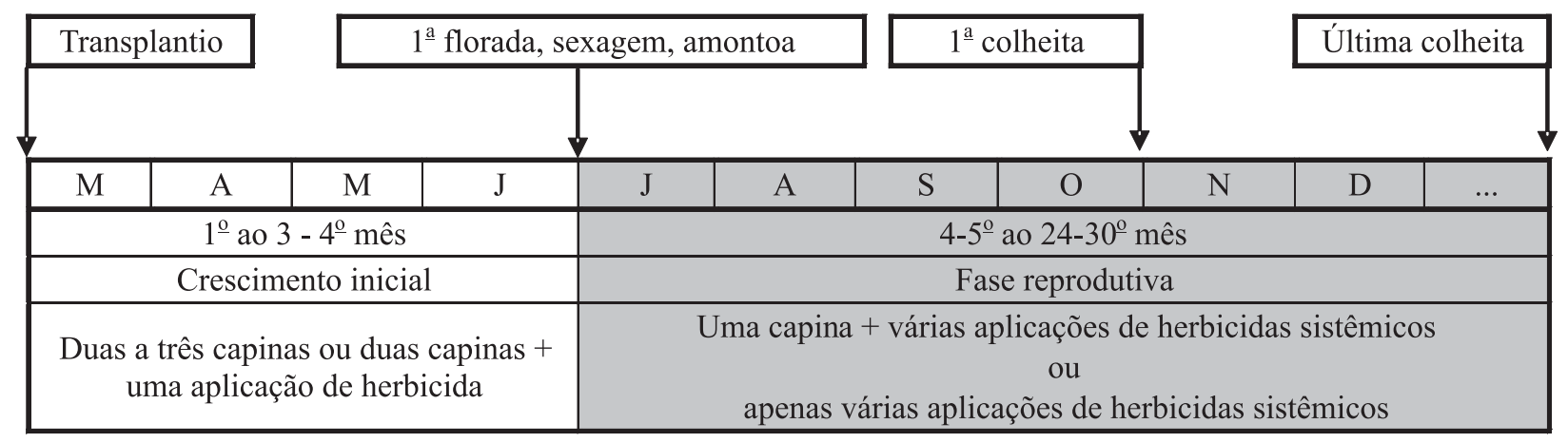

amontoa; e o controle de plantas daninhas é diferenciado em função do sistema de plantio ou tipo de irrigação: fileira simples - gotejamento; fileira dupla - microaspersão.

\section{Manejo integrado}

A manutenção do solo totalmente livre de plantas daninhas é uma prática não recomendável, pois favorece a sua degradação, além de ser de alto custo e desnecessária. O mamoeiro, como a maioria das culturas perenes, necessita que se mantenha limpa uma determinada área de solo ao redor do caule, para prevenir a interferência entre as plantas daninhas e a cultura, mantendo-se a vegetação na entrelinha (Bogantes \& Mora, 2004). Além disso, é na região de solo próximo ao caule da planta que se concentra a maioria do sistema radicular do mamoeiro (Masr, 1993; Costa \& Costa, 2003), principalmente devido à irrigação e ao uso intenso de fertilizantes e de matéria orgânica nela localizados. No Brasil, em Linhares, a cobertura verde do solo, entre as linhas de plantio, é praticada por $40 \%$ dos produtores (Martins, 2003). É importante considerar também que, nas regiões em que o mamoeiro é cultivado, o clima caracteriza-se por elevadas temperaturas e fortes ventos. Esses fatores, aliados ao solo predominantemente de textura arenosa a média e aos amplos espaçamentos em que a cultura é plantada, podem trazer grandes prejuízos ao solo, degradando-o, caso a vegetação na entrelinha não seja mantida. Na Costa Rica, por exemplo, há grande preocupação com a sustentabilidade do ambiente, particularmente com a erosão (hídrica) do solo e lixiviação dos nutrientes, uma vez que nas áreas produtoras registram- se precipitações pluviais variando de 2.500 a $4.500 \mathrm{~mm}$ anuais (Bogantes \& Mora, 2004).

Atualmente, nas lavouras comerciais, principalmente após o transplantio, o controle de plantas daninhas é feito em faixa, sendo a largura desta definida de forma aleatória, visto que nenhum estudo foi realizado sobre esse tema. A faixa de controle deve ser ampla o bastante para evitar o estabelecimento da competição, mas, ao mesmo tempo, mínima o suficiente para reduzir o custo de controle e manter a superficie do solo na entrelinha protegida. Torna-se necessário, portanto, sobretudo para plantios feitos em fileira simples, definir a largura da faixa de controle de plantas daninhas de cada lado da linha de plantio, para que não ocorra interferência com a cultura. Um trabalho realizado na Costa Rica (Bogantes \& Mora, 2004) sugere uma faixa de $0,60 \mathrm{~m}$ de cada lado da linha de plantio como adequada para evitar a competição das plantas daninhas com a cultura.

Quando o mamão é cultivado em consórcio com outras culturas, $\mathrm{o}$ manejo das plantas daninhas nas culturas consorciadas pode favorecer o mamoeiro (Sauls \& Campbell, 1980). Contudo, o hábito de crescimento da cultura consorciada deve ser considerado para garantir a máxima produtividade do mamoeiro. Por exemplo, o consórcio de mamão com caupi (Vigna unguiculata) reduziu a biomassa das plantas daninhas em mais de $90 \%$, não sombreou o mamoeiro e aumentou o rendimento da cultura. Todavia, algumas combinações com milho e/ou feijão-de-vagem causaram sombreamento e reduziram a produtividade da cultura (Nishimoto, 1997). Na Índia, culturas de cobertura como Amaranthus sp. e Mentha sp. 
são usadas tanto para controle de plantas daninhas como para aumentar a produtividade do mamoeiro. Entretanto, quando essas plantas são colhidas, o controle manual de plantas daninhas deve ser reintroduzido (Challa, 1995).

Nas regiões produtoras de mamão da Bahia e do Espírito Santo (Tabuleiros Costeiros), em que predominam solos de fácil compactação e com presença marcante de camada adensada subsuperficialmente, o manejo integrado de plantas daninhas, particularmente a manutenção da cobertura vegetal (introduzida ou natural) na entrelinha, tem apresentado resultados positivos (Carvalho et al., 2004; Carvalho, 2005; Santana et al., 2005). O cultivo de espécies como Canavalia ensiformis, Crotalaria juncia e Vigna unguiculata, além de propiciar a cobertura e proteção do solo, promove a ciclagem de nutrientes, via grande aporte de massa seca à superfície, que é de extrema importância naquele sistema, principalmente considerandose a pouca profundidade do sistema radicular do mamoeiro (Carvalho, 2005). Não menos importante, as leguminosas promovem redução da massa seca de plantas daninhas na lavoura, diminuição significativa no banco de sementes (Santana et al., 2005) e melhoria das propriedades fisicas do solo (Carvalho et al., 2004).

Na Nigéria, Akinyemi et al. (2006) avaliaram diferentes métodos de controle (capina manual, controle químico e consórcio com abóbora-amarela, abóbora-branca e amendoim) de plantas daninhas (Commelina benghalensis, Cynodon dactylon, Imperata cylindrica, Mariscus umbellatus e Panicum maximum) na cultura do mamão com o objetivo de selecionar um método de controle cultural ou alternativo tão eficiente quanto o controle químico. Entretanto, verificaram que este controle proporcionou maior produtividade da cultura e melhor controle de plantas daninhas que os demais tratamentos; não houve diferença no controle de plantas daninhas entre os consórcios com abóboras e destes com a capina manual, porém a lavoura consorciada com abóboras produziu mais que aquelas em que a capina manual foi empregada. Akinyemi et al. (2006) recomendam o uso do consórcio com abóbora-branca para o controle cultural de plantas daninhas na cultura do mamão, mesmo diante de redução de produtividade do mamoeiro em $13 \%$.
Provavelmente, a produção da cultura consorciada deve compensar essa perda. É importante ressaltar, entretanto, que as cucurbitáceas, de forma geral, são hospedeiras do vírus do mosaico e sua presença na lavoura deve ser evitada, para prevenir a disseminação de viroses (Ventura et al., 2003; Martins \& Ventura, 2007).

Apesar do apelo agroecológico da manutenção da vegetação natural (plantas daninhas) na entrelinha de cultivo, principalmente na produção integrada de mamão (Martins, 2003; Ruggiero et al., 2003; Carvalho, 2005), existem riscos associados a essa prática, que geralmente forçam os agricultores a eliminar toda a vegetação na lavoura, pois muitas espécies de plantas daninhas são hospedeiras de afideos vetores do vírus causador de uma das principais doenças da cultura do mamoeiro: o mosaico (Ventura et al., 2003). Também conhecido como mancha anelar, o mosaico representa $68 \%$ das viroses que acometem a cultura (Martins, 2003) e pode causar perdas elevadas caso as plantas doentes não sejam eliminadas tão logo apareçam os primeiros sintomas (Ventura et al., 2003). Não obstante, algumas plantas daninhas também são hospedeiras de cochonilhas - insetos que se constituem num importante problema fitossanitário dessa cultura (Culik et al., 2007; Martins, 2007).

A região produtora de mamão do Espírito Santo apresenta elevado número de plantas daninhas hospedeiras de pulgões associado à cultura (Lima et al., 2003b; Rocha et al., 2005; Martins et al., 2007; Martins \& Ventura, 2007). Nesse caso, as dez principais espécies de plantas daninhas foram Bidens pilosa, Chamaesyce hirta, C. hyssopifolia, C. benghalensis, Emilia coccinea, E. sonchifolia, Gnaphatium spicatum, Malvastrum americanum, Sida spp. e Solanum americanum (Lima et al., 2003b). Das 31 espécies hospedeiras de pulgões, $S$. americanum (maria-pretinha) foi a que apresentou maior número desses insetos (apesar de não ser a mais freqüente), seguida de $C$. benghalensis (trapoeraba), que se destacou também por ser a espécie com maior freqüência de infestação (Lima et al., 2003b). S. americanum mostrou-se hospedeira de Aphis fabae e $C$. benghalensis; $B$. pilosa e Amaranthus spp. foram hospedeiras de Aphis gossypii (Lima et al., 2003b). Trabalhos de Martins et al. (2005, 2007) e Rocha 
et al. (2005) também evidenciam, independentemente do sistema de produção e tipo de irrigação, que $C$. benghalensis é a espécie mais importante naquela região, por ser hospedeira de maior número de espécies de afídeos e por estar associada à cultura do mamão durante todo o ano. Em outras regiões do mundo, como, por exemplo, nas Filipinas, algumas espécies de plantas daninhas (Diplocyclos palmatus) são hospedeiras do próprio virus do mosaico (Magdalita et al., 1990).

A população de afideos geralmente é maior nas lavouras do sistema integrado que nas do sistema convencional de produção, provavelmente devido à presença (ou à obrigatoriedade da manutenção) da cobertura vegetal na entrelinha daquele sistema, ainda que o número de plantas de mamoeiro infectadas não tenha se alterado (Lima et al., 2003a). Em Cuba, Mederos-Olalde et al. (2000) verificaram que o número de plantas doentes (viróticas) foi $7.088 \%$ superior em lavouras sem o controle do mato, comparadas àquelas com controle em área total. Logo, as plantas daninhas foram indiretamente o principal fator responsável pelas doenças viróticas (Mederos-Olalde et al., 2000).

Certamente, um dos grandes desafios dessa cultura, particularmente da produção integrada de mamão, será o de eliminar, de forma seletiva, somente as plantas daninhas hospedeiras dos pulgões, mantendo-se a cobertura vegetal natural (não-hospedeira de vetores) na lavoura. É importante ressaltar que determinadas espécies de plantas daninhas podem contribuir para a manutenção de elevadas populações de inimigos naturais dos pulgões. Tomados em conjunto, esses aspectos permitem concluir que em lavouras de mamão completamente infestadas por $C$. benghalensis (o que é muito comum) a adoção da produção integrada é, conceitualmente, inviabilizada. O mesmo não ocorre com a produção convencional de mamão, uma vez que uma das medidas de controle recomendadas para diminuir a disseminação do mosaico é manter o pomar (e suas vizinhanças) no limpo, para evitar a formação de colônias de afideos nas plantas daninhas (Ventura et al., 2003).

\section{Herbicidas}

O controle de plantas daninhas nas lavouras de mamão do Estado do Espírito Santo é feito exclusivamente com herbicidas em 34\% das propriedades, e com herbicidas associados a outros métodos de controle em $56 \%$ do total (Martins, 2003).

Assim como para a maioria das culturas, as plantas de mamão recém-transplantadas são muito sensiveis à interferência das plantas daninhas que ocorrem na linha de plantio, podendo ter seu crescimento e ciclo reprodutivo comprometidos caso o controle não seja efetuado em tempo hábil. No entanto, manejar plantas daninhas na linha de plantio do mamoeiro constitui-se em tarefa difícil, pois o controle manual é dispendioso e, muitas vezes, impossivel de ser realizado, haja vista a escassez de mão-de-obra e a umidade excessiva do solo; o controle químico carece de herbicidas seletivos para esta fase da cultura, registrados para uso em pré ou pós-emergência, bem como de tecnologias adequadas à aplicação de herbicidas não-seletivos, semelhantemente ao que se verifica em lavouras de café (Ronchi et al., 2001). Além disso, o controle manual de plantas daninhas na linha de plantio, com o uso de enxadas, tem causado ferimentos no sistema radicular (provavelmente por este ser superficial; Masr, 1993; Costa \& Costa, 2003) e no caule do mamoeiro, além de prejudicar o sistema de irrigação (perfuração das mangueiras de gotejamento) (Ferregueti, comunicação pessoal). Esses fatos demonstram a necessidade de pesquisar e desenvolver tecnologias alternativas de controle de plantas daninhas na linha de plantio dessa cultura.

O manejo de plantas daninhas na linha de plantio deve visar à manutenção dessa área no limpo. Teoricamente, isso pode ser conseguido utilizando-se de herbicidas seletivos aplicados em pré ou pós-emergência das plantas daninhas ou por meio de herbicidas não-seletivos, aplicados em jato dirigido à linha de plantio, sob a copa das plantas de mamão, evitando-se a deriva. Todavia, para a cultura do mamoeiro, no Brasil, não existem herbicidas registrados que apresentem seletividade total para serem aplicados diretamente sobre as plantas desta cultura, em pré ou pós-emergência das plantas daninhas (Martins, 2003; Rodrigues \& Almeida, 2005; MAPA, 2008). Além disso, são escassas as pesquisas que visam selecionar, entre os herbicidas registrados para as culturas em geral, aqueles com potencial 
para serem usados em lavouras de mamão recém-transplantadas, com aplicação em área total.

O glyphosate (que é o único herbicida registrado para a cultura do mamoeiro no Brasil - MAPA, 2008, em cultivo convencional) tem sido usado em pós-emergência, sobretudo em lavouras adultas de mamão, para controle nãoseletivo de plantas daninhas nesta cultura no Brasil (Martins, 2003; Rodrigues et al., 2003) ou na Costa Rica (Guzmán, 1998). Inclusive, pleiteia-se, junto ao Ministério da Agricultura, Pecuária e Abastecimento, o registro do glyphosate para uso na produção integrada de mamão (Martins, 2003; Rodrigues et al., 2003). Não se têm observado injúrias ao mamoeiro ou redução da produtividade pelo uso de aplicações repetidas desse herbicida, desde que seja aplicado de forma dirigida às plantas daninhas, sem que as folhas e as partes verdes do caule do mamoeiro sejam atingidas. Por isso, além do uso de tecnologia de aplicação adequada, principalmente para se evitar ou reduzir a deriva, recomendam-se aplicações em lavouras cujas plantas estejam com altura superior a $1,1 \mathrm{~m}$, o que pode ocorrer entre 4 e 12 meses após o transplantio (Romanowski et al., 1972; Nishimoto \& Hibbard, 1979; Nisimoto, 1997).

Assim como em outras culturas perenes (café e citros, por exemplo), a trapoeraba encontrou, nas lavouras de mamão, condições favoráveis ao seu ótimo desenvolvimento e, por isso, está amplamente disseminada e presente durante todo o ano, particularmente nas lavouras do norte do Estado do Espírito Santo. A atual predominância dessa espécie nas lavouras é resultado, provavelmente, da eliminação da interferência das outras plantas daninhas (Ramos \& Durigan, 1996), pela aplicação continuada de glyphosate, uma vez que a trapoeraba é tolerante a esse herbicida (Ronchi et al., 2002a). Apesar da ineficiência do glyphosate no controle de trapoerabas, esse herbicida é muito utilizado nas lavouras de mamão, visto que controla de modo eficaz praticamente quase a totalidade das demais plantas daninhas, particularmente as Poaceae, e é de baixo custo. Considerando-se que a trapoeraba é de ampla ocorrência nas lavouras (Martins, 2003) e sua presença é indesejável, uma vez que é hospedeira de insetos (pulgões) vetores do vírus do mosaico do mamoeiro, há a necessidade de identificar outros tratamentos herbicidas eficientes para manejo dessa planta daninha nas lavouras de mamão, principalmente aqueles formados pela combinação de herbicidas. Existem herbicidas com potencial para seu controle (Ronchi et al., 2002a,b), porém são necessárias pesquisas para comprovar a eficácia no controle de trapoeraba nessa cultura e definir as doses adequadas, viabilidade econômica e ambiental, bem como as possiveis injúrias sobre a cultura. Na cultura do café, aplicações seqüenciais de glyphosate, em intervalos de 20 dias, permitem controle eficiente de trapoerabas (Ronchi et al., 2001).

Apesar de herbicidas recomendados para uso em pré-emergência (de outras plantas cultivadas) praticamente não serem utilizados em lavoura de mamão em semeadura direta, provavelmente em razão da tolerância marginal apresentada pela cultura (Nishimoto, 1997), alguns têm potencial sem injuriar a cultura, como oryzalin, pendimethalin e alachlor, porém com efeitos dependentes do tipo de solo e eficiência sobre poucas espécies de plantas daninhas (Nishimoto et al., 1973; Nishimoto, 1981). Contudo, na cultura transplantada, a tolerância das plantas aos herbicidas aplicados em pré-emergência é aumentada (Nishimoto et al., 1973, Nishimoto, 1981). Por exemplo, imediatamente após o transplantio, as plantas de mamão toleram o oryzalin, se este for dirigido à área de solo próxima ao caule do mamoeiro; todavia, se usado entre sete e nove semanas após o transplantio, estando as plantas com 8-15 cm de altura, esse herbicida pode ser aplicado diretamente sobre as plantas de mamão (Nishimoto, 1981, 1993).

A tolerância do mamoeiro a herbicidas utilizados em pré-emergência geralmente aumenta com a idade da planta ou com seu estádio de desenvolvimento (Nishimoto, 1997). Apenas oryzalin apresenta-se como herbicida eficiente para aplicação inicial, imediatamente após o transplantio, porém anterior à emergência das plantas daninhas, e a aplicação pode ser repetida durante todo o ciclo da cultura. Uma vez que decorridos pelo menos dois meses do transplantio, o mamoeiro apresenta tolerância ao trifluralin e alachlor; do terceiro ao quarto mês após o transplantio, ou quando as plantas atingirem 1,2 m de altura, a tolerância ocorre para o oxyfluorfen; entre seis meses e um ano de idade, as plantas 
toleram o diuron (Romanowski et al., 1972; Sauls \& Campbell, 1980; Nishimoto, 1981, 1993, 1997; Challa, 1988). Herbicidas como atrazine, simazine, ametryn, prometryn e bromacil causam severa injúria às plantas de mamão, resultando inclusive, em alguns casos, em redução de produtividade ou mesmo morte das plantas (Romanowski et al., 1972; Sauls \& Campbell, 1980; Bogantes \& Mora, 2004). De qualquer forma, a escolha do herbicida depende, também, entre outros fatores, das espécies de plantas daninhas presentes na área e, possivelmente, do genótipo de mamão cultivado. Ressalte-se que nenhum desses herbicidas está registrado no Brasil para uso na cultura do mamoeiro (MAPA, 2008).

Na Costa Rica, Bogantes \& Mora (2004) avaliaram o efeito de vários herbicidas aplicados em pré-emergência em duas épocas (aos 10 e 30 dias após o transplantio - DAT) sobre a cultura do mamoeiro (híbrido Pococí) e sobre o controle de plantas daninhas e obtiveram bom controle das plantas daninhas durante 90 DAT com a aplicação de oxyfluorfen + pendimethalin e acetochlor. Os dois primeiros herbicidas afetaram levemente as plantas de mamão na primeira época de aplicação (10 DAT), causando-lhes redução de crescimento e leve necrose nas brotações, mas houve total recuperação das plantas; aos 30 DAT, não causaram danos às plantas de mamão. $\mathrm{O}$ acetochlor não causou intoxicação ao mamoeiro em nenhuma época de aplicação (Bogantes \& Mora, 2004). Outras opções de herbicidas para controle de plantas daninhas na cultura do mamoeiro, em viveiros e no campo, assim como seus sintomas de intoxicação sobre a cultura e seus efeitos na qualidade do fruto, são apresentados e discutidos por Kumar et al. (1990), Challa (1988, 1995), Nishimoto (1997), Farmer's Bookshelf (2007) e Bogantes \& Mora (2004). Ressalte-se, apenas, que nenhum desses herbicidas está registrado no Brasil para uso na cultura (MAPA, 2008).

Em se tratando de tecnologia de aplicação de herbicidas nas lavouras de mamão, apesar da sua importância indiscutível para o sucesso do controle químico, não há qualquer registro de pesquisas científicas sobre o assunto. Herbicidas não-seletivos têm sido aplicados com pulverizadores costais manuais ou tratorizados e/ou com equipamento que permite aplicar o produto puro, em ultrabaixo volume. Para os pulverizadores costais, utilizam-se pontas de pulverização tipo leque 110.01 e 110.02 , vazão de 150 a $400 \mathrm{~L} \mathrm{ha}^{-1}$ e pressão de trabalho de 20 a $30 \mathrm{lb} \mathrm{pol}^{-2}$; para os tratorizados, utilizamse pontas de $80.03,80.03,110.03$ e 110.04 , em vazão de 200 a $400 \mathrm{~L} \mathrm{ha}^{-1}$ e pressão de 30 a $40 \mathrm{lb} \mathrm{pol}^{-2}$. O número de bicos varia com o espaçamento da lavoura. Nas aplicações tratorizadas é comum utilizar mangueiras acopladas aos tanques - reservatórios do produto. Geralmente, são utilizadas duas mangueiras, que possuem na sua extremidade barras semelhantes às do pulverizador costal manual. A essas barras são acopladas as pontas de pulverização e, comumente, o chapéu-de-napoleão.

Para aplicações em ultrabaixo volume, o frasco de um litro do produto comercial é acoplado diretamente ao equipamento e a aplicação é realizada por meio de gatilhos, de forma contínua ou intermitente, através da energia fornecida por pilhas, não sendo necessário, portanto, bombear. O equipamento é dotado de uma barra de $1,20 \mathrm{~m}$ de comprimento, que possui na extremidade uma campânula protetora de $0,35 \mathrm{~m}$ de diâmetro, sob a qual se adapta uma ponta de pulverização que aplica gotas de 150 a 300 micra, ideais para aplicação em ultrabaixo volume. O equipamento com o frasco do produto acoplado é leve, conferindo eficiência e praticidade durante a aplicação. O rendimento desse equipamento é de aproximadamente $3.000 \mathrm{~m}^{2} \mathrm{~h}^{-1}$ (Suporte Agrícola, 2008).

\section{CONSIDERAÇÕES FINAIS}

A otimização do manejo de plantas daninhas na cultura do mamoeiro é um campo totalmente em aberto para pesquisas científicas, sejam elas básicas ou aplicadas. A grande diversidade edafoclimática sob a qual o mamoeiro é cultivado, somada à diversidade elevada de genótipos existentes e aos vários sistemas de cultivo empregados, leva à necessidade de estudos de abrangência local ou no máximo regional. Com o advento da produção integrada de mamão, o manejo adequado das plantas daninhas ganha importância, necessitando de um tratamento diferenciado daquele dado ao manejo dessas plantas na produção convencional. É necessário, além de quantificar as 
perdas causadas pelas plantas daninhas à cultura, gerar informações técnico-científicas e práticas sobre biologia de plantas daninhas, espécies que ocorrem nas lavouras e que são hospedeiras de patógenos, estudos de competição e períodos de convivência, faixas de controle, freqüência de capinas e consorciamento. Não obstante, pesquisas sobre o controle químico de plantas daninhas - particularmente sobre a seletividade de herbicidas à cultura (em função da idade da planta após o transplantio), a eficiência de controle das plantas daninhas e tecnologias de aplicação de herbicidas - são de grande aplicabilidade.

A seleção de herbicidas para uso em pré e pós-emergência - por exemplo, com potencial para serem utilizados na cultura do mamoeiro recém-implantada, em aplicação apenas na linha de plantio - poderia contribuir para: redução no número de operações de cultivo; aumento do rendimento operacional do controle de plantas daninhas; redução da necessidade de capina manual e liberação de mão-de-obra para outras atividades, como, por exemplo, para a colheita, visto que as áreas de cultivo são muito extensas; controle de plantas daninhas em épocas chuvosas; redução de danos mecânicos ao sistema radicular e ao caule do mamoeiro e, também, ao sistema de irrigação, devido à redução do uso de enxadas na linha de plantio; maior proteção do solo pela manutenção da vegetação na entrelinha e controle apenas na linha de plantio, local em que de fato ocorre a competição (desde que as espécies presentes na área não sejam hospedeiras de patógenos da cultura); e menor tráfego de máquinas nas lavouras e, conseqüentemente, menos danos de compactação do solo. Tomadas em conjunto, essas informações resultariam em redução no custo de produção e melhoria da sustentabilidade do ambiente.

\section{LITERATURA CITADA}

AKINYEMI, S. O. S. et al. Growth, yield and productivity response of 'Sunrise Solo' papaya to weed management strategies. Biol. Agric. Hortic., v. 23, n. 4, p. 383-392, 2006.

BLANCO, H. G.; OLIVEIRA, D. A.; PUPO, E. I. H. Período de competição de uma comunidade natural de mato em uma cultura de café em formação. Biológico, v. 48, n. 1, p. $9-20,1982$.
BOGANTES, A.; MORA, E. Factibilidad técnica de la utilización de cobertura vegetal en papaya (Carica papaya L.) mediante la aplicación localizada de herbicidas. Agron.

Mesoam., v. 15, n. 2, p. 193-199, 2004.

BRASIL. Ministério da Agricultura, Pecuária e Abastecimento - MAPA. Agrofit: sistema de agrotóxicos fitossanitários. Disponível em: $<$ http:// extranet.agricultura.gov.br/agrofit $>$. Acesso em: 6 de jan. de 2008 .

BUCHANAN, G. A.; MURRAY, D. S.; HAUSER, E. W. Weeds and their control in peanut. In: PATEE, H. E.; YOUNG, C. T. (Eds.). Peanut science and technology. Yoakum: American Peanut Research and Education Society, 1982. p. 206-249.

CARVALHO, J. E. B. et al. Leguminosas e seus efeitos sobre propriedades físicas do solo e produtividade do mamoeiro 'Tainung 1'. R. Bras. Frutic., v. 26, n. 2, p. 335-338, 2004.

CARVALHO, J. E. B. Manejo de solos e cobertura verde em solos de tabuleiros costeiros para o cultivo do mamão. In MARTINS, D. S. (Ed.). Papaya Brasil: mercado e inovações tecnológicas para o mamão. Vitória: Incaper, 2005 p. $111-125$

CARVALHO, J. E. B. Manejo e controle de plantas daninhas em fruteiras. R. Seahortes, n. 1, p. 43-48, 2003.

CHALLA, P. Studies on chemical weed control in papaya (Carica papaya L.) orchards. South. Indian Hortic., v. 36, p. $285-289,1988$.

CHALLA, P. Weed control in papaya: a review. Weed News, v. 2, n. 1/2, p. 45-50, 1995.

COSTA, A. F. S. et al. Plantio, formação e manejo da cultura In: MARTINS, D. S.; COSTA, A. F. S. (Eds.). A cultura do mamoeiro: tecnologias de produção. Vitória: Incaper, 2003. p. 127-159

COSTA, A. F. S.; COSTA, A. N. Distribuição do sistema radicular do mamoeiro em solos de tabuleiros costeiros. In: MARTINS, D. S. (Ed.). Papaya Brasil: qualidade do mamão para o mercado interno. Vitória: Incaper, 2003. p. 395-400.

CULIK, M. P.; MARTINS, D. S.; VENTURA, J. A. Cochonilhas (Hemiptera: Coccoidea) como potenciais pragas do mamoeiro no estado do Espírito Santo. In: MARTINS, D. S.; COSTA, A. N.; COSTA, A. F. S. (Eds.). Papaya Brasil: manejo, qualidade e mercado do mamão. Vitória: Incaper, 2007. p. 519-526

FARMER'S BOOKSHELF. Papaya. Disponível em: <http:/ /www.ctahr.hawaii.edu/fb/papaya $>$. Acesso em: 19 de dez. de 2007.

Planta Daninha, Viçosa-MG, v. 26, n. 4, p. 937-947, 2008 
GUZMÁN, G. Guía para el cultivo de papaya (Carica papaya L.). Serie cultivos no tradicionales. MAG. San José, Costa Rica: 1998. 74 p.

INSTITUTO BRASILEIRO DE GEOGRAFIA E ESTATÍSTICA - IBGE. Levantamento sistemático da produção agrícola municipal 2006. 2008. Disponível em: <ftp://ftp.ibge.gov.br/Producao_Agricola/ Producao_Agricola_Municipal_\%5Banual\%5D/2006/>. Acesso em: 25 de abril de 2008

KUMAR, T. K. et al. Effect of herbicides on quality of papaya Carica papaya. Environ. Ecol., v. 8, n. 4, p. 12581261, 1990.

LIMA, R. C. A. et al. Flutuação populacional de afídeos associada à ocorrência do mosaico do mamoeiro na região norte do estado do Espírito Santo. In: MARTINS, D. S. (Ed.). Papaya Brasil: qualidade do mamão para o mercado interno. Vitória: Incaper, 2003a. p. 530-534.

LIMA, R. C. A. et al. Ocorrência de plantas hospedeiras de afídeos em sistemas de produção integrada e convencional de mamão no pólo de fruticultura de Linhares-ES. In:

MARTINS, D. S. (Ed.). Papaya Brasil: qualidade do mamão para o mercado interno. Vitória: Incaper, 2003b. p. 535-538.

MAGDALITA, P. M.; BAYOT, R. G; VILLEGAS, V. N. Diclocyclos palmatus L. Jeffrey: a new weed host of papaya ringspot virus. Philippine J. Crop. Sci., v. 15, n. 3, p. 163168, 1990.

MARIN, S. L. D. et al. Recomendações para a cultura do mamoeiro dos grupo Solo e Formosa no estado do Espírito Santo. 4.ed. Vitória: EMCAPA, 1995. 57 p. (Circular Técnica, 3).

MARTINS, D. S. Cochonilhas do mamoeiro: espécies, comportamento de infestação, parasitismo, plantas hospedeiras e controle químico e hidrotérmico. In: MARTINS, D. S.; COSTA, A. N.; COSTA, A. F. S. (Eds.). Papaya Brasil: manejo, qualidade e mercado do mamão. Vitória: Incaper, 2007. p. 129-148.

MARTINS, D. S. et al. Espécies e hospedeiros de afídeos associados à cultura do mamoeiro (Carica papaya L.) no norte do estado do Espírito Santo. In: MARTINS, D. S. (Ed.). Papaya Brasil: mercado e inovações tecnológicas para o mamão. Vitória: Incaper, 2005. p. 447-452.

MARTINS, D. S. et al. Ocorrência de espécies de afídeos em áreas comerciais de mamão no estado do Espírito Santo. In: MARTINS, D. S.; COSTA, A. N.; COSTA, A. F. S. (Eds.). Papaya Brasil: manejo, qualidade e mercado do mamão. Vitória: Incaper, 2007. p. 496-501.
MARTINS, D. S. Situação atual da produção integrada de mamão no Brasil. In: MARTINS, D. S. (Ed.). Papaya Brasil: qualidade do mamão para o mercado interno. Vitória: Incaper, 2003. p. 95-128.

MARTINS, D. S.; VENTURA, J. A. Vetores de doenças do mamoeiro: monitoramento e controle. In: MARTINS, D. S.; COSTA, A. N.; COSTA, A. F. S. (Eds.). Papaya Brasil: manejo, qualidade e mercado do mamão. Vitória: Incaper, 2007. p. $113-128$

MASR, M. Rooting pattern and distribution of absorbing roots of papaya (Carica papaya L.) var. Eksotica. MARDI Res. J., v. 21, n. 2, p. 99-104, 1993.

MEDEROS-OLALDE, E. J.; HERRERA-ISLA, L.; QUINONES-RAMOS, R. Influence of the control of undesired vegetation on the loss of production in the culture of pawpaw (Carica papaya L.) subject to the appearance of virus sumptoms. Centro Agrícola, v. 27, n. 3, p. 35-38, 2000 .

NISHIMOTO, R. K. Herbicide options for weed control in papaya. Integr. Pest Manag. Rev., v. 2, p. 109-111, 1997.

NISHIMOTO, R. K. Herbicide studies for weed control in Carica papaya. Proc. Asian-Pacific Weed Sci. Soc. Conference, v. 8, p. 57-61, 1981.

NISHIMOTO, R. K. Oxyfluorfen tolerance and weed control in young papaya. Intern. J. Pest Manag., v. 39, n. 3, p. 366-369, 1993.

NISHIMOTO, R. K.; HIBBARD, K. L. Glyphosate for weed control in Carica papaya. In: Proc. Asian-Pacific Weed Sci. Soc. Conference, v. 11, p. 71-73, 1979.

NISHIMOTO, R. K.; ZANDSTRA, B. H.; KRATKY, B. A. Herbicides for papaya. In: ANNUAL HAWAII PAPAYA INDUSTRY ASSOCIATION CONFERENCE, 9., 1973, Honolulu. Proceedings... Honolulu: University of Hawaii College of Tropical Agriculture and Human Resources Publication, 1973. v. 9. p. 18-30.

PITELLI, R. A. Interferência de plantas daninhas em culturas agrícolas. Inf. Agropec., v. 120, n. 11, p. 16-27, 1985.

RADOSEVICH, S. R.; HOLT, J.; GHERSA, C. Weed ecology: implication for managements. New York: John Wiley \& Sons, 1996. 589 p.

RAMOS, H. H.; DURIGAN, J. C. Avaliação da eficiência da mistura pronta de glyphosate $+2,4-\mathrm{D}$ no controle da Commelina virginica L. em citrus. Planta Daninha, v. 14, n. 1, p. 33-41, 1996. 
ROCHA, M. A. M.; MARTINS, D. S.; LIMA, R. C. A. Levantamento fitossociológico das plantas daninhas, na cultura do mamão, sob diferentes sistemas de irrigação, nos municípios de Linhares e Sooretama - ES. In: MARTINS, D S. (Ed.). Papaya Brasil: mercado e inovações tecnológicas para o mamão. Vitória: Incaper, 2005. p. 327-331.

RODRIGUES, B. N.; ALMEIDA, F. S. Guia de herbicidas. 5.ed. Londrina: 2005. 648 p.

RODRIGUES, N. R. et al. Estudo de resíduos de glifosato em mamão. In: MARTINS, D. S. (Ed.). Papaya Brasil: qualidade do mamão para o mercado interno. Vitória: Incaper, 2003. p. 703-706

ROMANOWSKI, R. R. et al. Herbicide selectivity trials with papayas (Carica papaya) in Hawaii. Honolulu, University of Hawaii College of Tropical Agriculture and Human Resources Publication, 1972. (Hawaii Agricultural Experiment Station Research Report, 181)

RONCHI, C. P. et al. Carfentrazone-ethil, isolado e associado a formulações de glyphosate no controle de duas espécies de trapoeraba. Planta Daninha, v. 20, n. 1, p. $103-$ $113,2002 \mathrm{a}$

RONCHI, C. P. et al. Misturas de herbicidas para o controle de plantas daninhas do gênero Commelina. Planta Daninha v. 20 , n. 2 , p. $311-318,2002$ b.

RONCHI, C. P.; SILVA, A. A.; FERREIRA, L. R. Manejo de plantas daninhas em lavouras de café. Viçosa, $M G$ : Universidade Federal de Viçosa, 2001. 94 p
RUGGIERO, C. et al. Panorama da cultura do mamão no Brasil e no mundo: situação atual e tendências. In: MARTINS, D. S. (Ed.). Papaya Brasil: qualidade do mamão para o mercado interno. Vitória: Incaper, 2003. p. 11-34.

SANTANA, I. S. et al. Emergência e matéria seca de plantas daninhas na cultura do mamoeiro (Carica papaya). Planta Daninha, v. 23, n. 4, p. 583-588, 2005.

SAULS, J. W.; CAMPBELL, C. W. Herbicide screening on Carica papaya L. Proc. Am. Soc. Hortic. Sci. Trop. Region, v. 24, p. 93-96, 1980.

SISTEMA DE INFORMAÇÕES AGROMETEOROLÓGICAS - SIAG. Dados médios da série histórica da estação meteorológica localizada no município de Linhares-ES. 2008. Disponível em: <http:// siag.incaper.es.gov.br>. Acesso em: 6 de jan. de 2008.

SUPORTE AGRÍCOLA. Pulmipur: aplicador de glifosato puro. Disponível em: $<$ http:/ www.suporteagrícola.com.br> Acesso em: 25 de abril de 2008.

VENTURA, J. A.; COSTA, H.; TATAGIBA, J. S. Manejo das doenças do mamoeiro. In: MARTINS, D. S.; COSTA, A. F. S. (Eds.). A cultura do mamoeiro: tecnologias de produção. Vitória: Incaper, 2003. p. 231-308. 